\title{
Towards interoperability on Northwest European railway corridors: signalling on the high-speed railway Amsterdam-Antwerp
}

\author{
J. H. Baggen, J. M. Vleugel \& J. A. A. M. Stoop \\ Delft University of Technology, The Netherlands
}

\begin{abstract}
The high-speed railway Amsterdam (The Netherlands)-Antwerp (Belgium) is nearly completed. As part of a TEN-T priority project it will connect to major metropolitan areas in Northwest Europe. In many (European) countries, high-speed railways have been built. So, at first sight, the development of this particular high-speed railway should be relatively straightforward. But the situation seems to be more complicated. To run international services full interoperability is required. However, there turned out to be compatibility problems that are mainly caused by the way decision making has taken place, in particular with respect to the choice and implementation of ERTMS, the new European railway signalling system. In this paper major technical and institutional choices, as well as the choice of system borders that have all been made by decision makers involved in the development of the high-speed railway Amsterdam-Antwerp, will be analyzed. This will make it possible to draw some lessons that might be used for future railway projects in Europe and other parts of the world.
\end{abstract}

Keywords: high-speed railway, interoperability, signalling, metropolitan areas.

\section{Introduction}

Two major new railway projects were initiated in the past decade in The Netherlands, the Betuweroute dedicated freight railway between Rotterdam seaport and the Dutch-German border and the high-speed railway between Amsterdam Airport Schiphol and the Dutch-Belgian border to Antwerp (Belgium). Both projects were severely delayed. The Betuweroute railway was opened in the summer of 2007. Since then, only a very limited number of trains 
have used this railway. The high-speed railway to Antwerp is still not operational at all and it is not yet known when opening of the railway is due. Serious problems with respect to the installation of the European Rail Traffic Management System (ERTMS) are responsible for this situation.

This paper concentrates on the question whether the technical, institutional and organisational setting of the project was to a certain, maybe even considerable, extent responsible for this situation. It is mainly based on a study by a specialized team of Delft University of Technology for Dutch parliament [1]. Parliament had the impression that the Ministry of Transport, responsible for the management of the project in the Netherlands did not do its work well enough. It ordered an independent study dealing in particular with the following questions:

- How did the delays occur?

- $\quad$ Could these delays have been prevented and if so, how?

- What lessons can be learned from this project for new, large-scale infrastructure projects in the future?

In fact, this paper deals with two projects, the Dutch 'HSL-Zuid' and the Belgian 'HSL 4' counterpart, together connecting Amsterdam Airport Schiphol and Antwerp. Where appropriate, railway signalling systems in other countries in Europe have also been studied, because of the fact that this high-speed railway project is part of the Trans-European Transport Networks (TEN-T). The development of a high-speed railway may be a new phenomenon for the Netherlands, but this is not the case in other (European) countries. In these countries high-speed passenger trains are already operating for several decades. Until now high-speed trains in The Netherlands are using conventional tracks only for services to France (Thalys trains) and to Germany (ICE trains). Maximum speed is limited to $140-160 \mathrm{~km} / \mathrm{h}$ only instead of $200-300 \mathrm{~km} / \mathrm{h}$. As a consequence, passengers do not (fully) benefit from the main benefit of these trains: fast and comfortable transport of passengers over long distances [2].

This paper consists of the following sections. The project HSL-Zuid/HSL 4 and ERTMS are discussed in section 2. In the sections 3 to 5 choices related to the project are discussed. In section 3 the technical choice of the new ERTMS is compared with proven technology, in section 4 the institutional choice of PPP is compared with traditional contracts and in section 5 the choice of the national boundary as project boundary is compared with system boundaries as project boundary. Finally, in section 6 the main conclusions of this paper can be found.

\section{The high-speed railway Amsterdam-Antwerp and ERTMS}

Questions relating to the ERTMS implementation as planned for the HSLZuid/HSL 4 are discussed in this section.

This high-speed railway was built between the years 2000 and 2006 [3]. It consists of conventional (Amsterdam-Schiphol, Rotterdam station, Breda station and Antwerp-Brussels) and high-speed sections. Figure 1 shows the high-speed railway HSL-Zuid/HSL 4. The railway is part of the 'Priority Project No. 2' of the Trans-European Transport Networks (TEN-T) also known as the 'high-speed railway Paris-Brussels-Köln (Cologne)-Amsterdam-London (PBKAL)' (see Figure 2). It is one of the last parts of Priority Project No. 2 to be completed. 


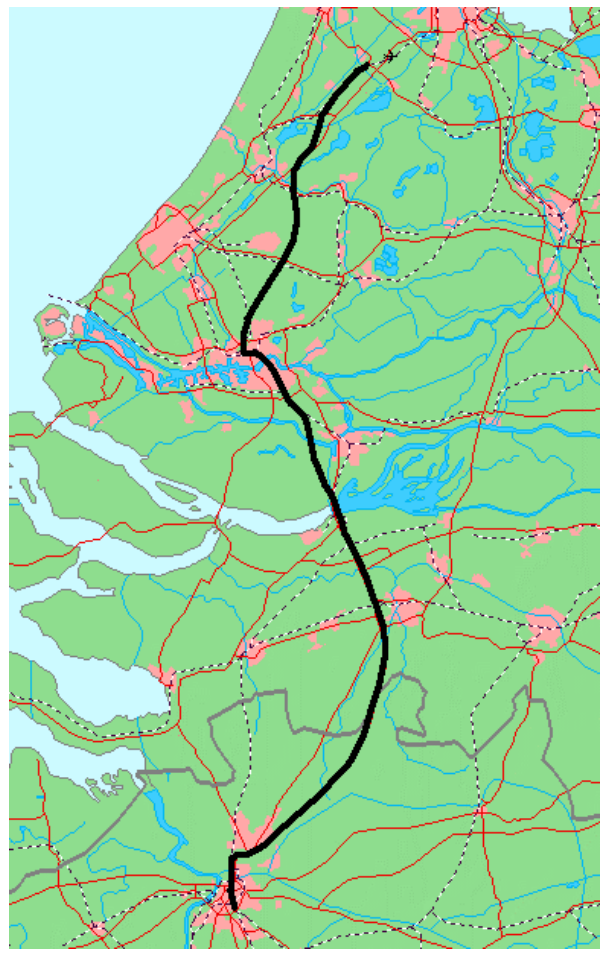

The new $300 \mathrm{~km} / \mathrm{h}$ high-speed sections are:

- HSL-Zuid (northern part):

Schiphol-Rotterdam

Central Station,

- $\quad$ HSL-Zuid (southern part):

south of Rotterdam-

Breda-Dutch/Belgian

border and

- HSL 4: Dutch/Belgian border-Antwerp.

Figure 1: HSL-Zuid/HSL 4 [4].

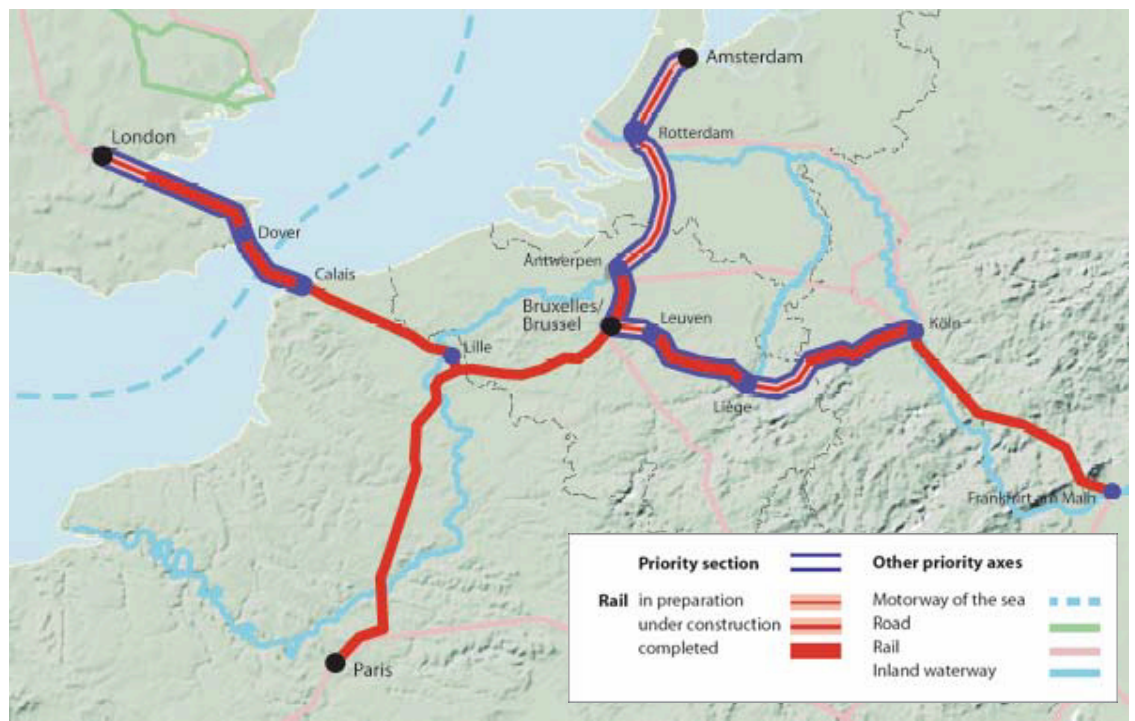

Figure 2: High-speed railway Paris-Brussels-Cologne-Amsterdam-London [5].

WIT Transactions on The Built Environment, Vol 103, (c) 2008 WIT Press www.witpress.com, ISSN 1743-3509 (on-line) 
Harmonisation and standardisation of national railway networks is a critical precondition for efficient cross-border (high-speed) railway traffic. Railway signalling is not standardised in Europe. Over 20 different signalling and speed control systems exist in Europe ([6]; Figure 3). As a consequence, a train has to be equipped with all the systems used on the tracks in the countries it passes. For instance, a Thalys train set has seven different signalling systems on board: TVM (France), TBL (Belgium), LZB (Germany), ATB (The Netherlands), Crocodile/Krokodil (Belgium), KVB (France) and PZB/Indusi (Germany) [7]. TVM, TBL and LZB have been developed for use on high-speed railways and the other four systems are for use on conventional railways. This large number of sometimes very different signalling systems unnecessarily complicates train protection (with a potentially negative impact on safety) and it strongly increases the purchase and maintenance costs of rolling stock and infrastructure [7].

In the future the European Commission wants all those different systems to be replaced by a new European Rail Traffic Management System (ERTMS). ERTMS is a system that consists of train control and communication, known as European Train Control System (ETCS), a dedicated mobile phone network for railways, known as GSM-R and the legal framework and operational procedures governing this system. The introduction of ERTMS is financially supported by the Commission. Interoperability is a key issue for the Netherlands and Belgium.

ETCS consists of layers with different technical requirements and applications (Levels 1-3). A higher level involves less track side equipment, but more on-board equipment. This change also implies that the costs of the signalling system will migrate from the infrastructure providers to the train operators. Table 1 gives an overview of the three main levels and their function in ERTMS.

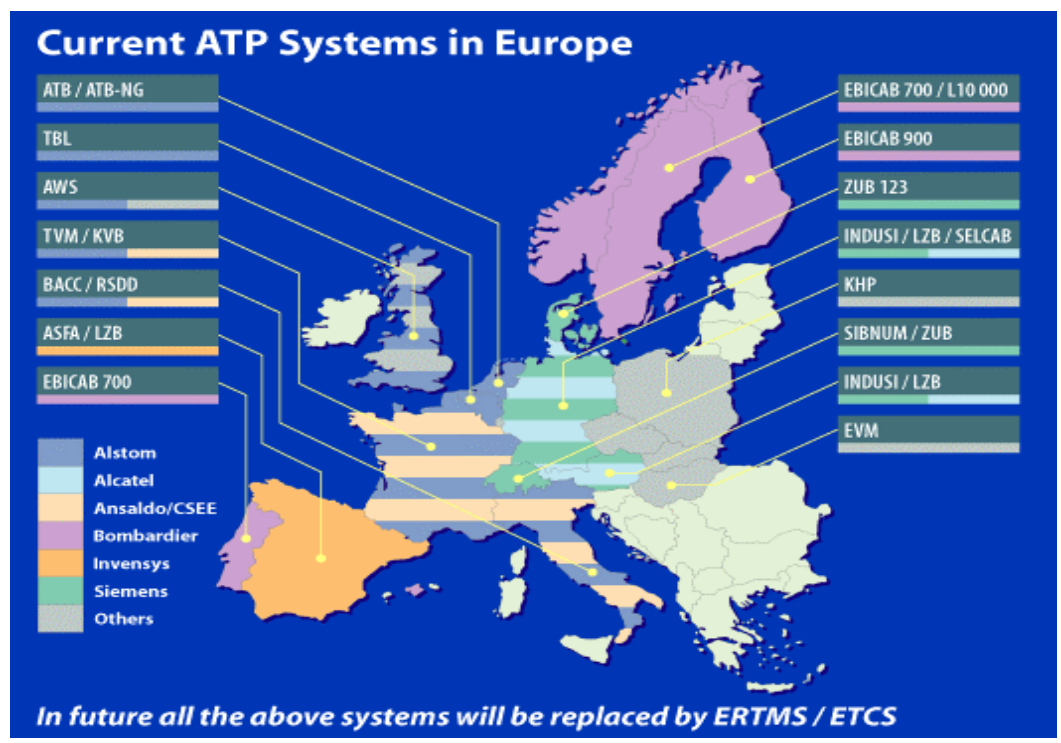

Figure 3: $\quad$ Signalling systems in Europe [6]. 
Table 1: $\quad$ ETCS levels and their function [4].

\begin{tabular}{|l|c|c|}
\hline & Protection & Detection \\
\hline Level 1 & infrastructure & infrastructure \\
Level 2 & train & infrastructure \\
Level 3 & train & train \\
\hline
\end{tabular}

The migration of present signalling systems to ERTMS is a long-term process. Suppliers of railway equipment are now introducing Levels 1 and 2. Level 2 is likely to be introduced on new tracks and Level 1 on existing tracks [8]. Several ETCS Level 1 installations are operational now. ETCS Level 2 installations in Switzerland and Italy are operational now, while the system on HSL-Zuid/HSL 4 has yet to be debugged (more about this later) $[9,10]$. Level 3 is regarded as an option for the future. Research that should result in technical specifications has been started, but implementation is not foreseen before 2011 [8]. ERRAC even mentions the year 2020 in its migration scenarios [11].

\section{Railway signalling: ERTMS or proven technology?}

In The Netherlands ERTMS as signalling system op HSL-Zuid has been chosen on a moment when only a functional specification existed and ERTMS was not yet in operation anywhere. The choice as such could be defended from the perspective of European standardization, but the risks (and costs) of development were unknown at the time. Therefore, from a business perspective it has been a high-risk (financial) choice. On other (international) high-speed railways the choice was made to install a proven signalling system. The French TGV signalling system TVM, for instance, had been installed on Paris-Brussels and more recently on the Channel Tunnel Rail Link to London and the LGV Est (on the latter: dual standard TVM430 and ERTMS Level 2 for POS-corridor to Germany).

The functional specification of ERTMS left some freedom for interpretation. This in turn had disastrous consequences: the two implementations made by Alcatel (for the Dutch part of the railway) and Alstom (for the Belgian part of the railway) turned out to be incompatible. To solve this serious problem, a 'dedicated' solution has been defined. It consists of a dedicated version of ERTMS (referred to as 'Version 2.3.0 Corridor') that replaces an earlier version and a link between the two systems of different suppliers by a so-called gateway: a system, that arranges the communication between the two ERTMS implementations and their Radio Block Centres on either side of the Dutch-Belgian border [12]. The gateway on HSL-Zuid/HSL 4 has yet to be debugged $[9,10]$.

This example shows that ERTMS as a European solution has not reached the original aim of full standardization, as with Version 2.3.0 Corridor, there is now standardisation at the level of 2 corridors only: PKBA (Paris-Brussels-Cologne/ Amsterdam) and POS (extended LGV Est: Paris-Ostfrankreich-Süddeutschland).

In The Netherlands for HSL-Zuid, the initial idea was to use an existing system, like e.g. TVM430, until ERTMS would become available. Later, a migration towards ERTMS only could be envisioned. There was a high level of optimism among suppliers that ERTMS would be available soon, while the step 


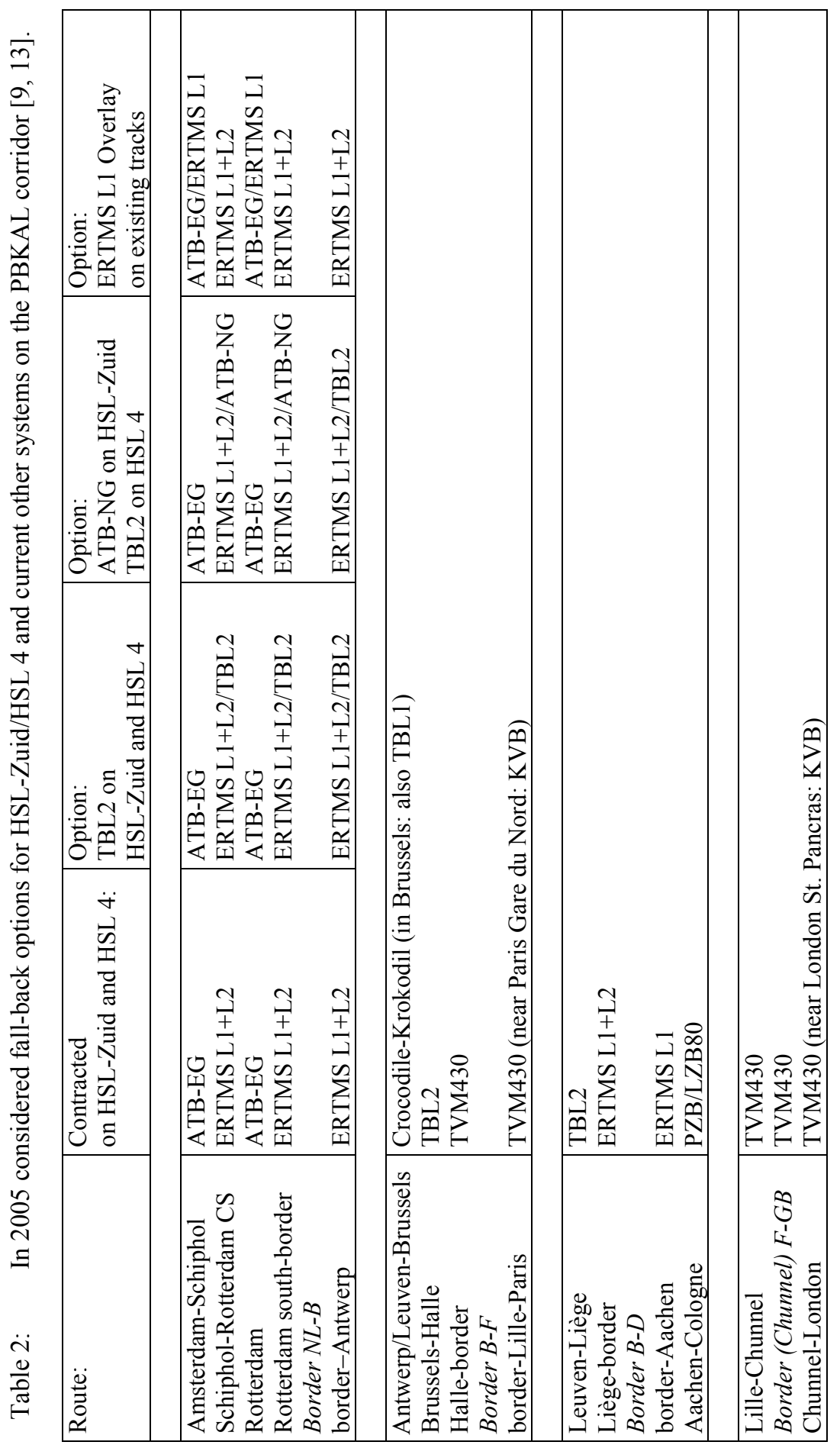

WIT Transactions on The Built Environment, Vol 103, (C) 2008 WIT Press www.witpress.com, ISSN 1743-3509 (on-line) 
from a temporary, initial system to ERTMS was regarded a high risk. Instead the choice was made to directly implement ERTMS. Interestingly, on the moment the Dutch contract was signed, it was still unclear whether Belgium would choose ERTMS on HSL 4 and, if so, from which supplier.

Since ERTMS was not a mature product, the discussion about the necessity and benefits of fall-back options continued. In 2003 TVM has been considered as an overlay (i.e. as fall-back option) on HSL-Zuid, just like the present implementation on the LGV Est [14]. This option was rejected. Later this discussion took place with the future operator HSA. The minister of Transport rejected the idea by referring to the additionally by Siemens installed ERTMS Level 1 as fall-back option and because in November 2005 it did not seem likely to install and certify one of three fall-back options as considered by HSL-Zuid and ProRail (TBL2, ATB-NG and ERTMS Level 1 Overlay) before the initially proposed opening date of April 1, 2007 [13]. Table 2 shows these fall-back options, together with an overview of other signalling systems in use on the PBKAL corridor.

The conclusion may be that a choice for the French dual standard approach, using TVM430 and ERTMS [14], would have been interesting, because this would have allowed through running of high-speed trains from Amsterdam to Brussels, Paris and beyond, as far as the Mediterranean and also from Amsterdam to London (via Lille) (see Table 2). Also, it would not be necessary to upgrade the existing Thalys train sets. Later, a (mature) ERTMS Level 2 could have been added. Instead of the now installed ERTMS Level 1 as a fall-back option on HSL-Zuid/HSL 4 (which still introduces a second signalling system next to ERTMS Level 2), TVM as a fall-back option next to ERTMS Level 2 would have been a good alternative because, unlike ERTMS Level 1 which allows train to operate with speeds up to $160 \mathrm{~km} / \mathrm{h}$, TVM allows speeds of $300 \mathrm{~km} / \mathrm{h}$.

\section{Institutional arrangements: PPP or traditional contracts?}

In The Netherlands it was decided to develop the HSL-Zuid project in a public private partnership (PPP). This has created a complex contract structure. The project was organised into 3 infrastructure projects and 1 transport project [3]:

- there are infrastructure projects for sub- and superstructure and for the connections with existing track by different building conglomerates. There is an agreement between the government of The Netherlands and a consortium called Infraspeed (including Siemens Nederland) to build the infrastructure. Another consortium is responsible for the connection with the existing network. Finally, the substructure project was divided into six agreements between the government and building consortia;

- there is one transport project involving a 15 year transport concession: an agreement between the government of The Netherlands and a consortium called High Speed Alliance (HSA, consisting of Dutch railways NS (90\%) and KLM Royal Dutch Airlines (10\%)).

The Belgian HSL 4 project has a totally different main structure of agreements:

- an infrastructure agreement (excluding signalling) between national railway operator SNCB/NMBS and TUC RAIL $[15,16]$; 
- $\quad$ an agreement on signalling between SNCB/NMBS and AILS (a consortium of Alstom and Siemens);

- $\quad$ a transport service contract, in which SNCB/NMBS is transport supplier.

Infraspeed partner Siemens contracted Alcatel to develop ERTMS Level 2 on HSL-Zuid. In Belgium, ERTMS Level 2 has been installed on HSL 4 by AILS partner Alstom. Siemens installs ERTMS Level 1 on the whole line, in The Netherlands (via Infraspeed) as well as in Belgium (via AILS). Infrastructure provider in The Netherlands is ProRail, while Infraspeed is responsible for maintenance, renewal and development. In Belgium Infrabel takes care of the infrastructure. HSA has an exclusive concession, which makes it the only supplier of domestic rail services on HSL-Zuid. For cross border services, HSA has to cooperate with the Belgian SNCB/NMBS and the French SNCF. There is no direct connection between the Dutch infrastructure and transport agreements, which means that Infraspeed and HSA do not have contractual liability against each other. However, these parties have a legal obligation to match their agreements.

The Dutch choice for a PPP has met criticism. In The Netherlands politics considered PPP as a goal as such [17] and not as a means to reach other goals. It may be concluded that the Dutch government systematically chose for marketoriented solutions, while the Belgian government preferred more traditional contracts. The complex contractual situation in The Netherlands could be one of the explanations for the technical difficulties on ERTMS.

\section{Project boundaries: national or system boundaries?}

Another reason, next to the choice for PPP, why the international HSL-Zuid/ HSL 4 project has been divided into two parts, was the choice for the national border as project demarcation instead of the system border. The latter is a point where the high-speed tracks connect with the existing tracks of the conventional railway system. If the system border would have been chosen instead, it would have been much easier to connect the signalling systems. For HSL-Zuid/HSL 4 this would have meant a connection of signalling systems in Rotterdam and Antwerp, but not at the national border. This would also save a Radio Block Centre.

The division of the project in two parts could have been avoided by The Netherlands in the treaty with Belgium in 1996. The Netherlands asked for a route that uses Belgian territory for a much longer part than proposed initially, in order to make Breda an additional high-speed train stop. Belgium accepted this only after The Netherlands agreed to pay the additional costs of NLG $823 \mathrm{~m}$ (about EUR 373m) [17]. So it may be concluded that The Netherlands have paid a substantial share of the cost of the Belgian HSL 4. However, The Netherlands did not use this favourable position to improve the integration of the Dutch and Belgian parts of the high-speed railway. Belgium, on the contrary, used the opportunity to ask even more from The Netherlands by linking the negotiations about this project with several other 'open' cases. The Netherlands did not play its cards in a proper way, otherwise the problems with standardisation might have been mitigated. It also may have missed the opportunity to achieve economies of scale and reduction of costs due to shared tendering. 


\section{Conclusions and recommendations}

Severe delays in the implementation of ERTMS on HSL-Zuid/HSL 4 are due to several factors. This paper shows that important technical, institutional and systems engineering choices had dramatic consequences. At the same time it became apparent that this should not have been necessary. Alternative developments that could have avoided the problems will be discussed below.

An important option in this case would have been a joint development by The Netherlands and Belgium of the HSL-Zuid/HSL 4 project, instead of the present situation in which both countries developed their parts of the railway as separate projects. A joint tender could have reduced the costs because of economies of scale. A good example is the joint Austrian-Italian project for the Brenner Base Tunnel (BBT), a $55 \mathrm{~km}$ long railway tunnel beneath the Brenner Pass, for which a so-called European Economic Interest Group was established.

Another option could have been the choice of a proven signalling system: e.g. TVM430 instead of ERTMS. Because HSL-Zuid/HSL 4 connects with France and the Thalys trains are also of French origin, it would have made sense to choose for the French TVM system. This would have been at least a sensible medium term solution. As soon as ERTMS would have become fully available, it could have replaced TVM as primary signalling system. What happened instead is that the risk of major parts of the product development of ERTMS became concentrated in the HSL-Zuid/HSL 4 project.

Also the choice of more traditional contracts instead of PPP could have been considered. The institutional settings of the project in The Netherlands and Belgium were completely different. The separation between the infrastructure and transport contracts as has been chosen in The Netherlands did not really make sense, because it became much more difficult to implement a reliable signalling system. By putting the project mainly in the hands of private partners, The Netherlands have created an unnecessary contractual complexity, which in turn made co-operation with Belgium much more difficult. One of the results of this situation is that there are now two different interpretations of ERTMS (Alcatel and Alstom) that will be connected in a rather synthetic way by a 'gateway'.

Finally, the choice of system boundaries instead of national boundaries as project boundary would have avoided compatibility problems. The choice of the national boundary as system boundary is one of the main reasons why the whole project has been delayed for several years. If the project would have been developed as one international cross-border project, most, if not all technical problems could have been prevented. The Netherlands could have made arrangements for planning the HSL-Zuid/HSL 4 as one project in the treaty with Belgium since The Netherlands have paid a substantial part of the HSL 4.

Based on the analysis in this paper, some recommendations can be made. First, the organisation of such projects can be improved if a government in its contracts with private companies finds a way to divide risks and costs in a proper way over the contract partners instead of being the principal risk taker, as in the present situation. Secondly, this assumes that what may be called technologydevelopment contracts receive the approval of independent experts in the field. 


\section{References}

[1] Stoop, J.A., Baggen, J.H., Vleugel, J.M., Kroes, J.L. de \& Vrancken, J.L.M., HSL-beveiligingssysteem ERTMS: een onafhankelijk onderzoek naar nut en noodzaak van de aanpassing van het HSL-beveiligingssysteem ERTMS. Report for the Onderzoeks- en Verificatiebureau van de Tweede Kamer der Staten-Generaal, Delft University of Technology: Delft, 2007.

[2] Vleugel, J.M., Baggen, J.H. \& Stoop, J.A.A.M., Decision making on ERTMS at the high-speed railway Amsterdam-Antwerp. Proc. $10^{\text {th }}$ int. conf. on application of advanced technologies in transportation, Athens, 2008.

[3] HSL-Zuid, Achtergronden \& geschiedenis (samenvatting), http://www.rijks waterstaat.nl/hsl/hslzuid/Achtergronden_en_geschiedenis/achtergronden.jsp, High-speed alliance; http://www.hslzuid.nl/hsl/organisatie/High_Speed Alliance/index.jsp \& Aanbesteding, http://www.hslzuid.nl/hsl/organisatie/ aanbesteding/index.jsp.

[4] Wikipedia, Hogesnelheidslijn Schiphol-Antwerpen, http://nl.wikipedia.org/ wiki/Hogesnelheidslijn_Schiphol__Antwerpen \& European Train Control System, http://nl.wikipedia.org/wiki/ European_Train_Control_System.

[5] European Commission, Trans-European Transport Network: TEN-T priority axes and projects 2005, Directorate-General for Transport and Energy: Brussels, 2005.

[6] ERTMS, Current ATP Systems in Europe, http://www.ertms.com.

[7] Viaene, D., De seininrichting bij de NMBS, NMBS: Brussels, 2005.

[8] CER, Annual report 2005/2006, Brussels, 2006.

[9] KEMA Rail Traffic Certification, RINA, Cetren, Attica Advies, EBC \& Arsenal Research, Survey of safety approvals for the first ERTMS implementations: analysis of integration of ERTMS systems. Final report WP3, 2007.

[10] Rijkswaterstaat, Voortgangsrapport 22 Hogesnelheidslijn-Zuid, 2008.

[11] ERRAC, Strategic rail research, Agenda 2020, Brussels, 2002.

[12] Algemene Rekenkamer, Risicobeheersing HSL-Zuid, Tweede Kamer, vergaderjaar 2006-2007, 31072, no.1-2, SDU: The Hague, 2007.

[13] LREHC Infraproject Services, Definitieve rapportage second opinion beveiligingssysteem in HSL-Zuid infrastructuur, 2005.

[14] Baudry, H., Desbazeille, B., Durand-Raucher, Y., Pellegrin, J. \& Schmitt, O., Augmentation de capacité de la ligne à grande vitesse Paris-Lyon, Rapport no. 2004-0085-01, Conseil Général des Ponts et Chaussées: Paris, 2004.

[15] TUC Rail, Het Belgische HSL-net, http://www.tucrail.be/nl/projecten/ Belgique_LGV.htm.

[16] Weide, M. van der, Hogesnelheidslijn Brussel-Amsterdam, afstudeerpresentatie, Saxion Hogeschool, http://lesmateriaal.saxion.nl/djk/ Afstuderen/Presentaties\%207-7-2005/M.\%20van\%20der\%20Weide.doc.

[17] Tijdelijke Commissie voor de Infrastructuur, Reconstructie HSL-Zuid: de besluitvorming uitvergroot, Tweede Kamer, vergaderjaar 2004-2005, 29283, no.8, SDU: The Hague, 2004. 